\title{
Health Factors in Islamic Perspectives and Its Relation to Sustainability with Case Study at Traditional Kampung Hulu Mosque, Malaysia
}

\author{
Ahmad Sanusi Hassan \\ School of Housing, Building and Planning \\ Universiti Sains Malaysia, Penang, Malaysia \\ Tel: 60-4-653-2835_E-mail: sanusi@usm.my, sanusi.usm@gmail.com
}

\begin{abstract}
The importance of this study is to analyse how health consideration integrated to the traditional mosque design in Malaysia. A literature review is conducted to understand the definition of health based on Islamic perspectives. The purpose is to identify its sustainability and relationship to the traditional mosque design. The literature study identifies three primary factors on health in the mosque design associated with natural lighting, rainwater discharge and wall openings. The qualitative analysis comprises design on natural lighting related to sun shading and indirect lighting, rainwater discharge related to rainwater deflection and leakages; and wall openings related to natural cross air ventilation and stack effect. Traditional Mosque at Kampung Hulu, Malacca is selected for the case study. The analysis shows that pyramid roof and its overhangs, open serambi (veranda) area and the recessed wall with wall openings at the ground and roof levels become the principle of the traditional mosque design in relation to the health factors. The analysis however finds the weaknesses that the mosque design does not apply window and screen louvers in the construction.
\end{abstract}

Keywords: Health, Islamic perspectives, Sustainable, Traditional mosque design

\section{Introduction}

The study discusses issues of health factors based on Islamic perspectives, and application of these factors which give an impact of sustainability to the traditional mosque design in Malaysia. The scope of this study is limited to qualitative study on the physical analysis of design factors on health. It does not cover the spiritual factors and quantitative analysis related to the design. The literature study is made to understand the definition of Islamic perspectives on health, and the traditional mosque design. The aim of this study is to identify the related factors which can be used as the indicators for healthy mosque design in Malaysia.

Kampung Hulu Mosque is selected for the case study. Its location is in the inner city of Malacca. The selection is based on the recognition by the Department of Museum and Antiquity Malaysia to this mosque as one of the oldest mosques in Malaysia. Analysis is conducted to measure the impacts of sustainability on health factors to this traditional mosque design. The results will identify the findings which become primary references as research contributions for the development of mosque design in this country. The literature review and qualitative analysis are obtained from the writing reports, journals and books, inspection to the measured drawings, observations from the site visits and a series of interviews with the local residents and Architecture Museum curator.

\section{Islamic Perspective on Health and Architecture}

Health is one of the most important factors in Islam. Based on a translation from Surah Al-Baqarah (verse 222) (Note 1) "Truly, Allah loves those who turn unto Him in repentance and loves those who purify themselves". From a Hadith (translation) narrated by At-Tarmizi, Rasulullah said that nothing is more preferred by Allah subhanahuwataala other than health. Concern on healthcare by the local authority is emphasised since the glory of Islamic civilisation. According to Syrakoy and Athena $(2007,184)$, cities in the pre-modern Islamic world had equipped with hospitals. Hospital is known as 'maristan', (Note 2) which means places of administering the sick. The building was divided into different sections for men and women and housed a variety of medical specialities including surgery, ophthalmology, gynaecology and a pharmacy. This shows as evidence that health becomes an important factor in Islam, and the Muslims should acquire healthy body when fulfilling the religious orders (ibadah).

There are 5 Islamic laws of Obligation (Wajib), Desirability (Sunat), Simple Permissibility (Harus), Undesirability (Makruh) and Prohibition (Haram). These five laws are termed as Ahkam Khamsah. (Note 3) Regarding to the Syariah Laws on health, whatsoever act done by the Muslim in this world which could bring 
harm and cause illness to human beings, animals and unloving things (environment) is considered as sinful (haram). Therefore, design based on the Islamic Laws plays a crucial role in architecture. The architects must acquire the knowledge associated with health factors when designing the buildings so that they can design buildings which can boost healthy condition to the occupants. The good design will be able to hinder the occupants (and for the public users) from gaining illness and diseases. Knowledge about health associated with building design becomes a principal element in Islamic architecture. Acquiring this knowledge is compulsory (wajib) by the Muslim architects, and application of this knowledge will be rewarded in day's afterlife (akhirat). Reward is also given for additional contributions (sunat) beyond the requirements because of creating something beneficial and good. If the building leads the occupants to unhealthy feeling, uncomfortable and illness condition, it is considered as sinful by the responsible Muslim architects. Due to this poor design, they are accounted as committed sin, and responsible to carry this offence in day's afterlife.

\section{Health Factors in Building Design}

Health is commonly associated with comfort level. In architecture, comfort level can be achieved by application of passive and active design elements. In contrast to active design, passive design is sustainable to the social, cultural and environmental perspectives (Eben Saleh 1999; Abu-Ghazzeh 1997), which offers healthy condition, and the design does not rely on mechanical system (Moujalled, Cantin \& Guarracino 2008). It uses resources from the natural surroundings which are associated with three basic natural elements - sun, wind and water. The presence of the sun, wind and water influences the geography of the region. The climate varies from one region to another depending on sunlight's intensity, wind's velocity and amount of rainwater, which give influences to environmental parameters - air-temperature, radiation, humidity and air-movement (Sekhar 1995). The purpose of the environmental oriented building design is to protect the occupants from direct sun's heat, solar radiation and luminosity, rainwater leakages. The design can improve indoor air temperature and humidity, day lighting fixtures and air quality and hinder the presence of polluted substances like germs, bacteria and funguses. In case with the tropical region, the passive design elements focuses on natural lighting, rainwater discharge and wall openings.

\subsection{Natural lighting}

The purpose of design on natural lighting is to tackle the problem of solar heating and glare to the interior building from direct sunlight. Sun shading and indirect sunlight are two primary factors under natural lighting category. Design with excellent natural lighting or day lighting is important to gain the comfort level for healthy environment. The design with appropriate building orientation avoids problems of solar heating and direct sunlight (Moujalled, Cantin \& Guarracino 2008). To gain comfort means to have efficient use of natural energy resources.

\subsubsection{Sun shading}

Providing shade from sunlight is necessary in tropical design. The purpose as noted by Binggeli (2003) is to avoid heats from sunlight to the building's interior, and poor design will increase the indoor temperature. Direct sunlight penetrates sun's (solar) heat with it, creating poor thermal comfort. The overheating indoor temperature causes uncomfortable to the occupants; as a result, this condition creates unhealthy indoor air environment. Direct sunlight exposure should be avoided in a warm and humid climate in a tropic; the design should integrate shading devices (Binggeli 2003) to gain passive cooling. Primary factors to achieve excellent sun shading are building orientation, roof shade, attached roof shade, screen louver and window louver. Without this roof shade, the building materials will expose to direct sunlight, which gain the sun's heat. These building materials will reradiate the heats to the indoor area, and consequently this radiation increases the indoor temperature.

\subsubsection{Indirect Sunlight}

Design a building in a tropical country which uses indirect sunlight is necessary for efficient use of light energy. The concept of day lighting reduces the use of electric energy (Edwards \& Torcellini 2002). The most unique way is to furnish diffused daylight into the building. This can be achieved by integrating sun shading devices as a part of the building design (Chella, Gentile \& Zazzini 2007). These devices diffuse the direct sunlight to indirect sunlight into the building. Therefore this method limits the problem of luminosity. Building orientation, roof shade, attached roof shade, screen louver and window louver are primary factors to gain for indirect sunlight.

\subsection{Rainwater Discharge}

Discharging rainwater becomes a crucial factor because the rain is frequent. Peninsular Malaysia is one of the regions, which has the highest rainfalls in the world from the two annual monsoons, northeast and southwest 
monsoons (Robequain 1954). This region receives high annual rainfall at an average of $2500 \mathrm{~mm}$. Excellent building design will hinder problem of rainwater deflections and leakages to ensure the design for healthy environment.

\subsubsection{Rainwater deflection}

With frequent rain, the probability of rainwater deflection's occurrences is high especially during torrential rains and when wind velocity is high. The roof works like a large umbrella as argued by the local architect Jimmy Lim (Powell 1993), and plays crucial role to ensure the rainwater discharged in efficient way to hinder the rainwater deflection from happening. Poor design will lead to rainwater penetration into the building and roof perimeters, which lead to fungous growth. Roof overhang, attached roof overhang, fascia board, screen louver and roof ridge board are important elements to block rainwater deflection from penetrating inside the building.

\subsubsection{Rainwater leakages}

Roof should have simplest design as possible that creates smooth rainwater flow from the roof discharged to the ground level. Design with roof form with complex roof ridges has high tendency of roof leakages. The rainwater will penetrated into the roof structures and then inside the building. The leakages cause dampness to the roof and building floor, which leads fungus growth, with germs and bacteria. The roof should work like a large single umbrella to hinder the building materials used in a construction of the building interiors from rainwater leakages and deflection. Simple pyramid roof form, roof overhangs and roof ridge board design are necessary for efficient rainwater discharged.

\subsection{Wall Openings}

Wall openings are crucial in tropical building design. These openings are doors, windows and their upper window openings, and roof window openings. The openings are for cross ventilation and stack effect for passive cooling of air temperature and humidity. In tropical region, high annual rainfall accelerates evaporation, which causes humidity. The vapour content has only a slight difference between day and night as well as throughout the year. The water vapour is normally from 19 to 24 grams per cubic metre which is twice that of England during the summer (Fisher 1964). Efficient indoor air ventilation creates 'cross air movement and induced air flow' reducing the air temperature and humidity level. This creates comfortable and healthy environment from sun's heat and high humidity as well as removing funguses, bacteria and germs from the indoor building.

\subsubsection{Cross air ventilation}

Efficient natural ventilation is necessary for excellent indoor air quality by inducing outside fresh air into the indoor building. Maximum wall openings will maximise cross air ventilation. The openings allow an increase of indoor air speed (Moujalled, Cantin, Guarracino 2008). Wall openings like doors, windows and upper windows at the ground level, and windows at the roof levels are important factors for cross air ventilation. The purpose is to dilute the existing polluted indoor air. Poor air ventilation causes indoor air pollution in the building rated as sick building, unhealthy for occupancy (Allard, Santamouris, \& Alvarez 1998). Brown and Deekay (2001, 182) argued that large wall openings with wind direction perpendicular to the openings (at its windward and leeward sides) has excellent cross air ventilation, creating high pressure at the inlet zone and low pressure at outlet zone (Melarango 1982, 321; \& Stavrakakis, Zervas, Sarimveis \& Markatos 2009). This air movement gives cooling effect to the indoor air temperature and humidity. With excellent design of cross air ventilation, it reduces the use of ceiling and wall fans.

\subsubsection{Stack effect}

Stack effect is upward and outward air flow due to induction of air pressure in the building. This condition occurs because the warm air is lighter that the cool air. The air pressure induces warm and polluted air to flow out through roof openings. As the warm air flow out, its absence is replaced by outdoor fresh cool air coming from the ground floor's window and door openings. This air circulation ensures the building has comfortable and healthy indoor environment. According to Klote (1991), this excellent upward and outward air pressure occurs as the air intake outside the building is as minimised as possible while the indoor space has a height as great as possible. Similar to cross air ventilation, doors, windows and upper windows at the ground level, and windows at the roof levels are important wall openings to induce the stack effect.

\section{Case Study on Kampung Hulu Mosque}

The case study is on Kampung Hulu Mosque (Figure 1). The reason for the selection is this mosque is one of the oldest mosques in Malaysia. The location of this mosque is It is currently under conservation programme by Malaccan Museum Foundation (Perbadanan Muzium Muzium Negeri Melaka known as PERZIM) as a part of the 
state government incentives when inner city of Malacca is recognised the World Heritage Site under the UNESCO's World Heritage Lists since July 2008 (Chua 2008). Kampung Hulu Mosque is under category of traditional Malay mosque design. This mosque has architectural design integrating Islamic identity and regional values. There is a claim by the local villagers that Kampung Hulu Mosque is the oldest mosque in Malacca and the second oldest mosque in Malaysia. It was built in 1720 AD (1141 Hijrah) (Note 4) by Dato' Shamsuddin Arom, the Malay representative during the Dutch colonisation (Dewan Islam 1994). The original construction materials were timbers and nypa roof but in 1892, most of these materials were replaced with bricks (PERZIM). No mosque constructed during the glory of the Kingdom of Malacca survives today because all of the mosques were destroyed by the Portuguese after the defeat of Malacca to Portuguese.

The scope on this study is limited to the usable space for congregational prayer areas (Figure 2). These areas comprise three zones, a prayer hall, mihrab and serambi. The study focuses on the original part of the mosque design. It does not comply with the additional parts of the mosque construction built after that due to fit the number of the local Muslims who perform congregational Friday prayer. The mosque orientation (kiblat) is at the kaabah, a square monument or building located in Mecca, Saudi Arabia.

In this region, the qiblat is at southeast to northwest direction. The plan size of the prayer areas has a square shape. The dimension is $13 \mathrm{~m} \times 13 \mathrm{~m}(43.5 \mathrm{ft})$. The main area for congregational prayers is a prayer hall (Figure $2 \& 3)$. It covers the largest area of the prayer areas. The dimension is $10.2 \mathrm{~m}(34 \mathrm{ft}) \times 8.5 \mathrm{~m}(25.5 \mathrm{ft})$. Serambi area (Figure 2) is a perimeter corridor or veranda area around the southwest, northeast and southeast parts of the prayer hall. Its width is $2.9 \mathrm{~m}(9.5 \mathrm{ft})$. Mihrab is niche area, a small prayer area for one person, the Imam who leads the congregational prayers. It has a size slightly larger than one prayer mat (sejadah), placed in this mihrab. Its size is $1.5 \mathrm{~m} \times 1.5 \mathrm{~m}(5.5 \mathrm{ft})$.

Mimbar (Figure 2\&3) is not part in the study because it is an object located in the prayer hall beside a mihrab. It is a standing and sitting place for Imam when he gives a khutbah (sermon) during Friday prayer. The other parts are minaret and ablution area because they are located outside the mosque. Minaret is a tower while ablution area is a square water ponds near serambi area constructed with bricks and cements for the Muslims to take ablution before conduction their prayer.

\section{Research Methodology and Result of the Analysis}

The analysis is to measure the level of influence of health factors to the traditional mosque design in Malacca with the case study at Kampung Hulu Mosque. It applies qualitative survey, an evaluation by the researcher using working drawings and site observations. This survey uses 3 different measurable scales of the Likert Model (Wikipedia 2009) as the followings:

a) poor (means poor level related to the health factor)

b) moderate (means moderate level of the health factor)

c) excellent (means moderate level of the health factor)

Intense evaluation can value the healthy level for public health and to identify its functions to a benign way for the end user. The survey will be made to three measurable factors which are natural lighting, rainwater discharge and wall openings. The results are as follows:

\subsection{Natural lighting}

\subsubsection{Sun Shading}

i. There is no doubt that the mosque has an excellent roof shade design (Figure 4). Pyramid roof is an excellent roof type as sun shading device.

ii. Three tiered roof concept makes a design of attached roofs (Figure 4) become important parts of the roof structures. There are two types of the attached roof system which are lower and upper attached roof. These attached roofs have roof overhangs, which provide excellent sun shades. The roofs block high angle sunlight from penetrating into the building. In addition, the design of open verandah area makes possible for a construction of recessed walls $3 \mathrm{~m}$ further inside the building. The reason is to avoid the walls from exposure to direct sunlight, which causes solar radiation. The attached roof overhangs work well blocking high angle $\left(45-75^{\circ}\right)$ sunlight. However, the attached roof overhang does not able to block solar radiation at northwest wall. The reason is unlike the other building perimeters, no open serambi area and recessed wall is built at this facade.

iii. Building orientation (Figure 5) in a tropical region has efficient design by applying rectangular plan with wide wall at north and south facade compared to narrow wall at east and west façade. However, Kampung Hulu Mosque does not have rectangular plan design. It has instead square plan design, which is not the design with excellent 
building orientation. The plan layout is more related to the roof design, which emphasizes on square based pyramid roof form.

iv. The traditional mosque does not apply screen louver in the design. Without the louvered fittings, the northwest and southeast façades are exposed to low angle $\left(0-45^{\circ}\right)$ sunlight. The northwest façade becomes more acute to solar radiation because it is exposed to evening sunlight at low $\left(0-45^{\circ}\right)$ and high $\left(45-75^{\circ}\right)$ angle orientation. The roof overhang is not wide enough to block the evening sunlight because it is not used as serambi area; as a result, no recessed wall is built at northwest façade.

v. There is no window louver used in the mosque design to block solar radiation.

\subsubsection{Indirect Sunlight}

i. Pyramid roof (Figure 4) with its overhangs gives excellent shades to block high angle direct sunlight. It diffuses to indirect sunlight.

ii. The attached roofs with their overhangs gives excellent protection from high angle direct sunlight. These protection works well with the presence of serambi areas and the recessed walls except at the northwest part due to no design of its serambi area and the recessed wall.

iii. The analysis finds that the overhang design does not mean to block low angle sunlight into the building due to an absence of screen louvers in the design. As a result, the northwest façade has poor high and low angle lighting design. For southeast façade design, having the low angle sunlight's penetration to the building interior is beneficial because this skin exposure to morning sunlight provides Vitamin D for skin's health.

iv. The traditional mosque design focuses on square plan layout, related to the pyramid roof design with its square plan layout and its attached roof overhangs. It does not have an emphasis on design based on the building orientation except the direction to the qiblat, which is excellent orientation following the sun path.

v. Window louver does not become part of the design in the mosque construction.

\subsection{Rainwater Discharge}

\subsubsection{Rainwater deflection}

i. The construction of roof and attached roof overhangs (Figure 4) with an addition to the open serambi area and the recessed wall are excellent design to hinder rainwater deflections.

ii. The construction of dominant roof ridge (Figure 4) jointing corners of two roof slopes is an excellent design to prevent rainwater deflection.

iii. Fascia boards (Figure 6) play a crucial role to protect the roof structures and ceilings fro rainwater deflection.

iv. No screen louver is used in the design to tackle the problem of rainwater deflection.

\subsubsection{Rainwater leakages}

i. Simple pyramid roof (Figure 4) is the best roof form for smooth rainwater flow from the roof to the ground level, and therefore hinder the problem of rainwater leakages.

ii. Roof overhangs is an excellent roof design to create smooth flow of the rainwater to the ground level.

iii. Roof ridge board (Figure 4) is an excellent design for the roof corners to prevent the roof leakages, which allow rainwater's penetration into the building.

\subsection{Wall Openings}

\subsubsection{Cross air ventilation}

i. There are three ground doors (Figure 2\&7) at each recessed wall. No ground door is at the northwest wall. They play a crucial role for natural cross air ventilation.

ii. There are three ground windows (Figure $2 \& 7$ ) at each recessed wall except only two at the northwest wall. They play a crucial role for natural cross air ventilation.

iii. Unlike in most of traditional mosques in Malacca, there is no construction of ground upper windows in Kampung Hulu Mosque. This gives a little impact on cross air ventilation. Based on the interviews and site observation, there are no comments on uncomfortable feeling on the indoor room's temperature in the praying hall. 
iv. There are a series of lower and upper roof windows (Figure 7\&8) built at the lower and upper roof segments for cross air ventilation.

\subsubsection{Stack effect}

i. The level of stack effect (Figure 9) is moderate because the prayer hall has large ground floor window, upper windows and door openings. This means the air intakes from the ground floor windows are high; as a result, it only induces low air pressure into the prayer hall. Lower roof window - Upper window openings at upper and middle segment of the three tiered pyramid roof (forming triple volume space design) give excellent design for stack effect.

ii. The construction of lower and upper roof windows are excellent design for the stack effect.

\section{Conclusion}

The analysis illustrates that health factors have a great influence to the traditional mosque design. Health is one of the principles of sustainability in the built environment and the traditional buildings have principle of climate-oriented architecture (Lin, Tan, Wang, Song, Zhu \& Zhai 2004). The approach on health factors as sustainable considerations is not new in traditional mosque design based on the Islamic perspectives. It is like a rediscovery of the traditional technique in order to regain the sustainability's concept. The analysis shows that the traditional mosque design has an emphasis on simple pyramid roof and its attached roof form as important elements to tackle the problem of direct sunlight, solar radiation and luminosity. The same concept with an addition of roof ridge and fascia boards is applied to have excellent rainwater discharge. Wall openings are crucial elements used in the mosque design. The wall openings are at the ground floor and the segmented roof's wall level. These openings induce natural cross ventilation and stack effect. Serambi area and recessed walls are the enhanced designed elements to tackle the problem of direct exposure from tropical sunlight, solar radiation, luminosity and rainwater deflection.

However the analysis finds that the traditional mosque design does not apply screen and window louvers as the design elements for health factors. The traditional mosque design are only relying on the roof overhang concept with open serambi area and the recessed walls to tackle the problem of solar radiation, luminosity and rainwater deflection. In case with the problem of solar radiation and luminosity, this concept only works well to block high angle sunlight but not to low angle sunlight. The presence of window and screen louvers is important because it can block the low angle sunlight's penetration into the building. Besides, the study finds that the emphasis is more to cross air ventilation compared to stack effect. The design has large window and door openings on the ground floor level. To upgrade the development of traditional mosque design, the study recommends the uses on screen and window louvers as the important design elements. This integration will improve the health level and its sustainability.

\section{Acknowledgment}

This paper is under research grant financed by Universiti Sains Malaysia.

\section{References}

Abu-Ghazzeh, T.M. (1997). Vernacular architecture education in the Islamic society of Saudi Arabia: Towards the development of an authentic contemporary built environment. Habitat International, 21 (2), 229-253.

Allard, F., Santamouris M., \& Alvarez S. (1998). Natural ventilation in buildings: A Design Handbook. London: Earthscan Publication.

Binggeli, C. (2003). Building systems for interior designers. New Jersey: John Wiley and Sons Inc.

Brown, G.Z., \& Deekay, M. (2001). Sun, wind and light: Architectural design strategies. (2 ${ }^{\text {nd }}$ ed.). New York: John Wiley \& Sons Inc.

Chella, F., Gentile, E., \& Zazzini, P. (2007). Natural light in new underground areas of a historical building. Proceedings of 6th International Conference on Sustainable Energy Technologies 5th -7th September, 2007 (SET2007), Santiago, Chile.

Chua, E. (2008). Unesco accepts George Town and Malacca as World Heritage Sites. The Star Online. [Online] Available: http://www.thestar.com (July 2008)

Dewan Islam. (May/June 1994). Kampung Hulu Mosque. Malacca: Department of Islamic Religion Malacca.

Eben Saleh, M.A. (1999). Reviving traditional design in modern Saudi Arabia for social cohesion and crime prevention purposes. Building and Environment, 34, 649-669. 
Edwards, L., \& Torcellini, P. (2002). A literature review of the effects of natural light on building occupants. Colorado: National Renewable Energy Laboratory.

Fisher, C.A. (1964). South-east Asia. London: Methuen and Co. Ltd.

Klote, J.H. (1992). A general routine for analysis of stack effect. Gaithersburg: National Institute of Standards and Technology.

Lin, B., Tan, G., Wang, P., Song, L., Zhu, Y., \& Zhai, G. (2004). Study on the thermal performance of the Chinese traditional vernacular dwellings in Summer. Energy and Buildings, 6, 73-79.

Melarango, M.G. (1982). Wind in architectural and environmental design. New York: Van Nostrand Reinhold.

Moujalled, B., Cantin, R., \& Guarracino, G. (2008). Comparison of thermal comfort algorithms in naturally ventilated office building. Energy and Buildings, 40, 2215-2223.

Powell, R. (1993). The Asian House: Contemporary Houses of Southeast Asia. Kuala Lumpur: Select Book Pte. Ltd.

Robequain, C. (1954). Malaya, Indonesia, Borneo, and the Philippines. London: Longmans, Green and Co.

Sekhar, S.C. (1995). Higher space temperatures and better thermal comfort - a tropical analysis. Energy and Buildings, 23, 63-70.

Stavrakakis, G.M., Koukou, M.K., Vrachopoulos, M., Gr., Markatos, N.C. (2008). Natural cross-ventilation in buildings: Building-scale experiments, numerical simulation and thermal comfort evaluation, Energy and Buildings, 40, 1666-1681.

Syrakoy, A.C. (2007). Health, spirituality and power in medieval Iberia. Cities in the Pre-Modern Islamic World: The Urban Impact of Religion, State and Society. A.K. Bennison \& A.L. Gascoigne (Eds.). New York: Routledge Taylor \& Francis Group, 177-194.

Wikipedia. (2010). Likert Scale. [Online] Available: http://en.wikipedia.org/wiki/Likert_scale (April 2010).

\section{Notes}

Note 1. Surah Al-Baqarah (verse 222), Al-Quran Al-Karim

Note 2. Māristān is an Arabic term meaning hospital which comes from the Persian word bimāristān.

Note 3. The Word Jurisprudence (Fiqh) in the Holy Qur'an and the Traditions by Martyr Ayatullah Murtada Mutahhari from http://www.imamreza.net/eng/imamreza.php?id=832 sourced by Dr Nizam bin Sahad, lecturer of Islamic Studies Department of School of Humanities, Universiti Sains Malaysia.

* Pahala means good and rewarding points which will be accumulated by Allah S.W.T for every good deed done by us.

** Dosa means bad and punishing points which will be accumulated by Allah S.W.T for every forbidden and bad deed done by us.

Note 4. Islamic calendar 
Table 1. Analysis on sun shading

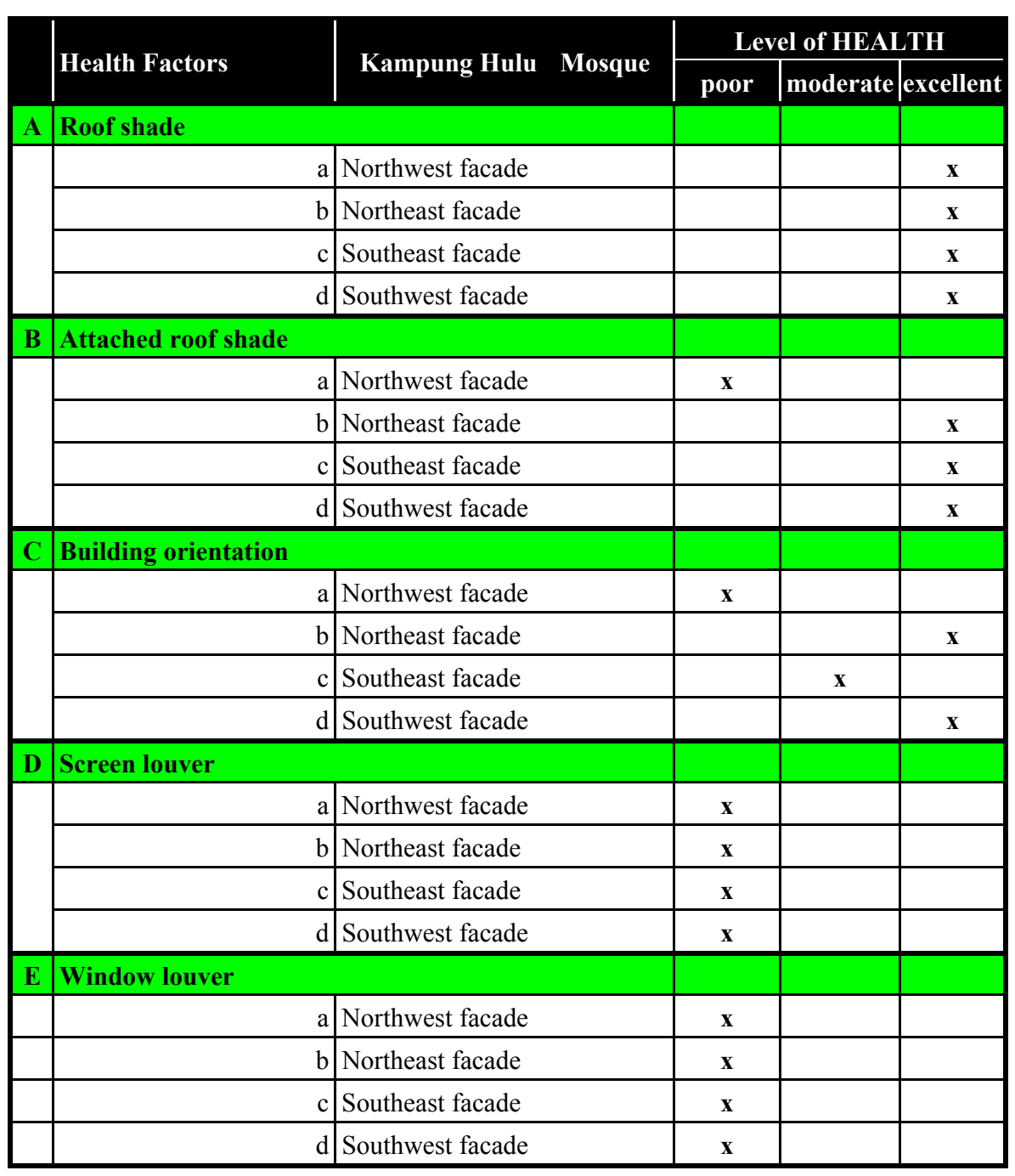


Table 2. Analysis on indirect sunlight

\begin{tabular}{|c|c|c|c|c|c|}
\hline & \multirow{2}{*}{ Health Factors } & \multirow{2}{*}{ Kampung Hulu Mosque } & \multicolumn{3}{|c|}{ Level of HEALTH } \\
\hline & & & poor & moderate & excellent \\
\hline \multirow[t]{5}{*}{ A } & \multicolumn{2}{|l|}{ Roof shade } & & & \\
\hline & $\mathrm{a}$ & Northwest facade & & & $\mathbf{x}$ \\
\hline & $\mathrm{b}$ & Northeast facade & & & $\mathbf{x}$ \\
\hline & $\mathrm{c}$ & Southeast facade & & & $\mathbf{x}$ \\
\hline & d & Southwest facade & & & $\mathbf{x}$ \\
\hline \multirow[t]{5}{*}{ B } & \multicolumn{2}{|l|}{ Attached roof shade } & & & \\
\hline & $\mathrm{a}$ & Northwest facade & $\mathbf{x}$ & & \\
\hline & $\mathrm{b}$ & Northeast facade & & & $\mathbf{x}$ \\
\hline & $\mathrm{c}$ & Southeast facade & & & $\mathbf{x}$ \\
\hline & d & Southwest facade & & & $\mathbf{x}$ \\
\hline \multirow[t]{5}{*}{$\mathrm{C}$} & \multicolumn{2}{|l|}{ Building orientation } & & & \\
\hline & $\mathrm{a}$ & Northwest facade & $\mathbf{x}$ & & \\
\hline & $\mathrm{b}$ & Northeast facade & & & $\mathbf{x}$ \\
\hline & $\mathrm{c}$ & Southeast facade & & $\mathbf{x}$ & \\
\hline & d & Southwest facade & & & $\mathbf{x}$ \\
\hline \multirow[t]{5}{*}{ D } & \multicolumn{2}{|l|}{ Screen louver } & & & \\
\hline & $\mathrm{a}$ & Northwest facade & $\mathbf{x}$ & & \\
\hline & $\mathrm{b}$ & Northeast facade & $\mathbf{x}$ & & \\
\hline & $\mathrm{c}$ & Southeast facade & $\mathbf{x}$ & & \\
\hline & d & Southwest facade & $\mathbf{x}$ & & \\
\hline \multirow[t]{5}{*}{$\mathbf{E}$} & \multicolumn{2}{|l|}{ Window louver } & & & \\
\hline & $\mathrm{a}$ & Northwest facade & $\mathbf{x}$ & & \\
\hline & $\mathrm{b}$ & Northeast facade & $\mathbf{x}$ & & \\
\hline & $\mathrm{c}$ & Southeast facade & $\mathbf{x}$ & & \\
\hline & d & Southwest facade & $\mathbf{x}$ & & \\
\hline
\end{tabular}


Table 3. Analysis on rainwater deflection

\begin{tabular}{|c|c|c|c|c|}
\hline & & & & el of HEALTH \\
\hline & Hetalin Tactors & Nampung hura Nosque & poor & moderate excellent \\
\hline A & Roof overhang & & & \\
\hline & $\mathrm{a} \mid \mathrm{I}$ & Northwest facade & & $\mathbf{x}$ \\
\hline & $\mathrm{b} \mid \mathrm{r}$ & Northeast facade & & $\mathbf{x}$ \\
\hline & c) $s$ & Southeast facade & & $\mathbf{x}$ \\
\hline & $\mathrm{d} \mid \mathrm{s}$ & Southwest facade & & $\mathbf{x}$ \\
\hline B & Attached roof overhang & & & \\
\hline & $\mathrm{a} \mid \mathrm{l}$ & Northwest facade & & $\mathbf{x}$ \\
\hline & $\mathrm{b} \mid \mathrm{I}$ & Northeast facade & & $\mathbf{x}$ \\
\hline & $\mathrm{c} s$ & Southeast facade & & $\mathbf{x}$ \\
\hline & $\mathrm{d} s$ & Southwest facade & & $\mathbf{x}$ \\
\hline C & Roof ridge board & & & \\
\hline & $\mathrm{a} / \mathrm{l}$ & Northwest facade & & $\mathbf{x}$ \\
\hline & $\mathrm{b} \mid \mathrm{I}$ & Northeast facade & & $\mathbf{x}$ \\
\hline & $\mathrm{c} s$ & Southeast facade & & $\mathbf{x}$ \\
\hline & $\mathrm{d} \mid \mathrm{s}$ & Southwest facade & & $\mathbf{x}$ \\
\hline D & Fascia board & & & \\
\hline & $\mathrm{a} / \mathrm{l}$ & Northwest facade & & $\mathbf{x}$ \\
\hline & $\mathrm{b} \mid \mathrm{l}$ & Northeast facade & & $\mathbf{x}$ \\
\hline & c) $s$ & Southeast facade & & $\mathbf{x}$ \\
\hline & $\mathrm{d} \mid \mathrm{s}$ & Southwest facade & & $\mathbf{x}$ \\
\hline $\mathbf{E}$ & Screen louver & & & \\
\hline & $\mathrm{a} / \mathrm{l}$ & Northwest facade & $\mathbf{x}$ & \\
\hline & $\mathrm{b} \mid \mathrm{r}$ & Northeast facade & $\mathbf{x}$ & \\
\hline & $\mathrm{c} s$ & Southeast facade & $\mathbf{x}$ & \\
\hline & $\mathrm{d} \mid \mathrm{s}$ & Southwest facade & $\mathbf{x}$ & \\
\hline
\end{tabular}


Table 4. Analysis on rainwater leakages

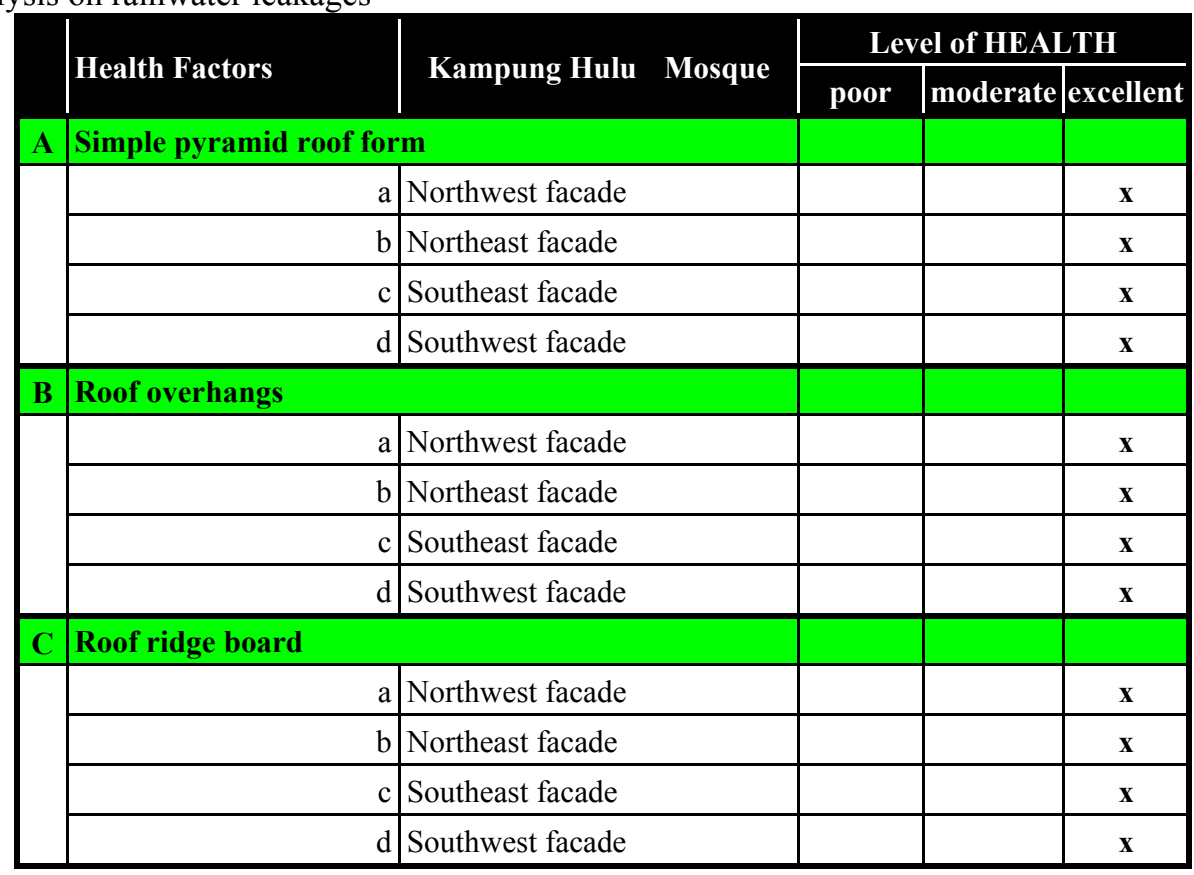

Table 5. Analysis on cross air ventilation

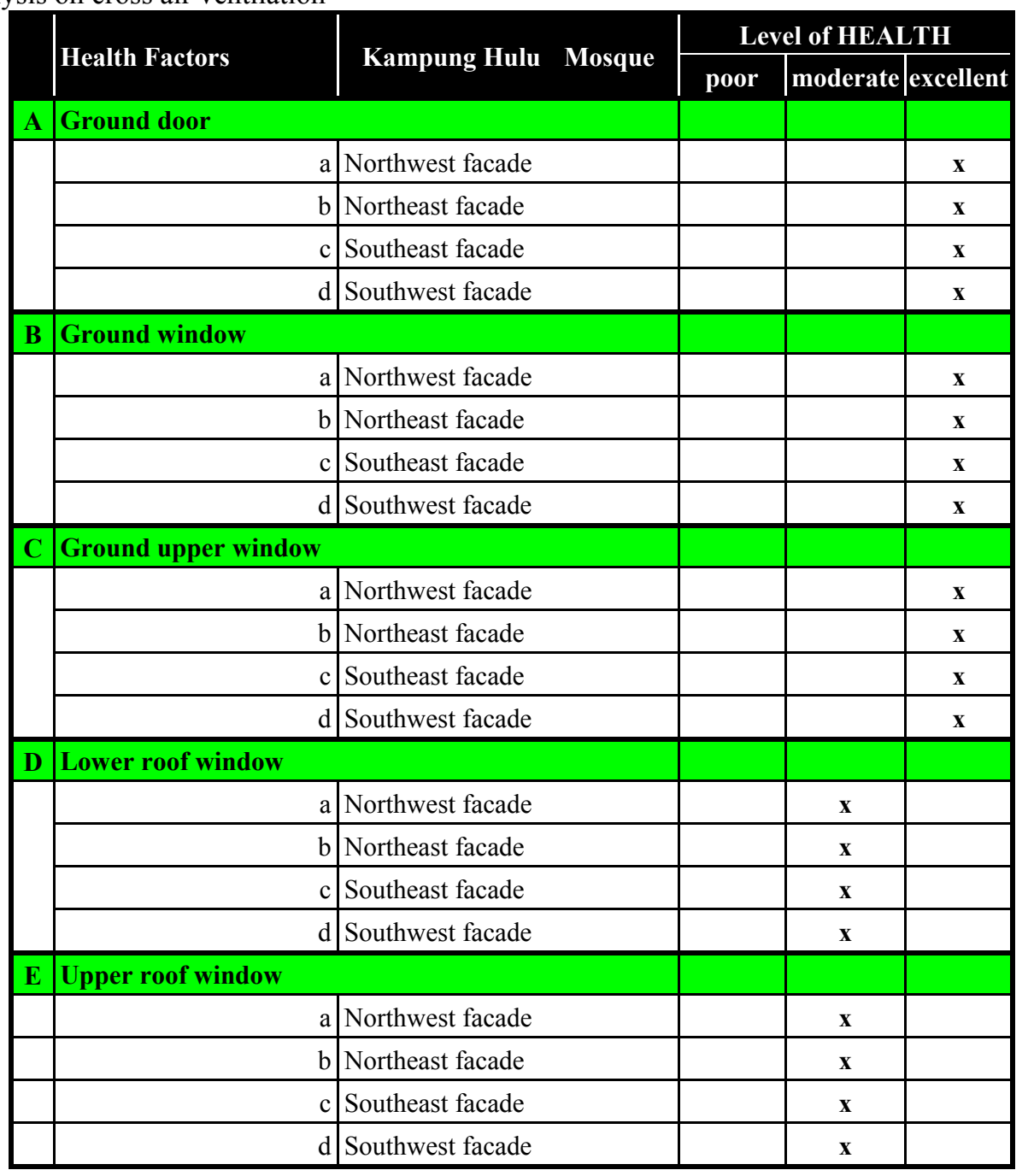


Table 6. Analysis on stack effect

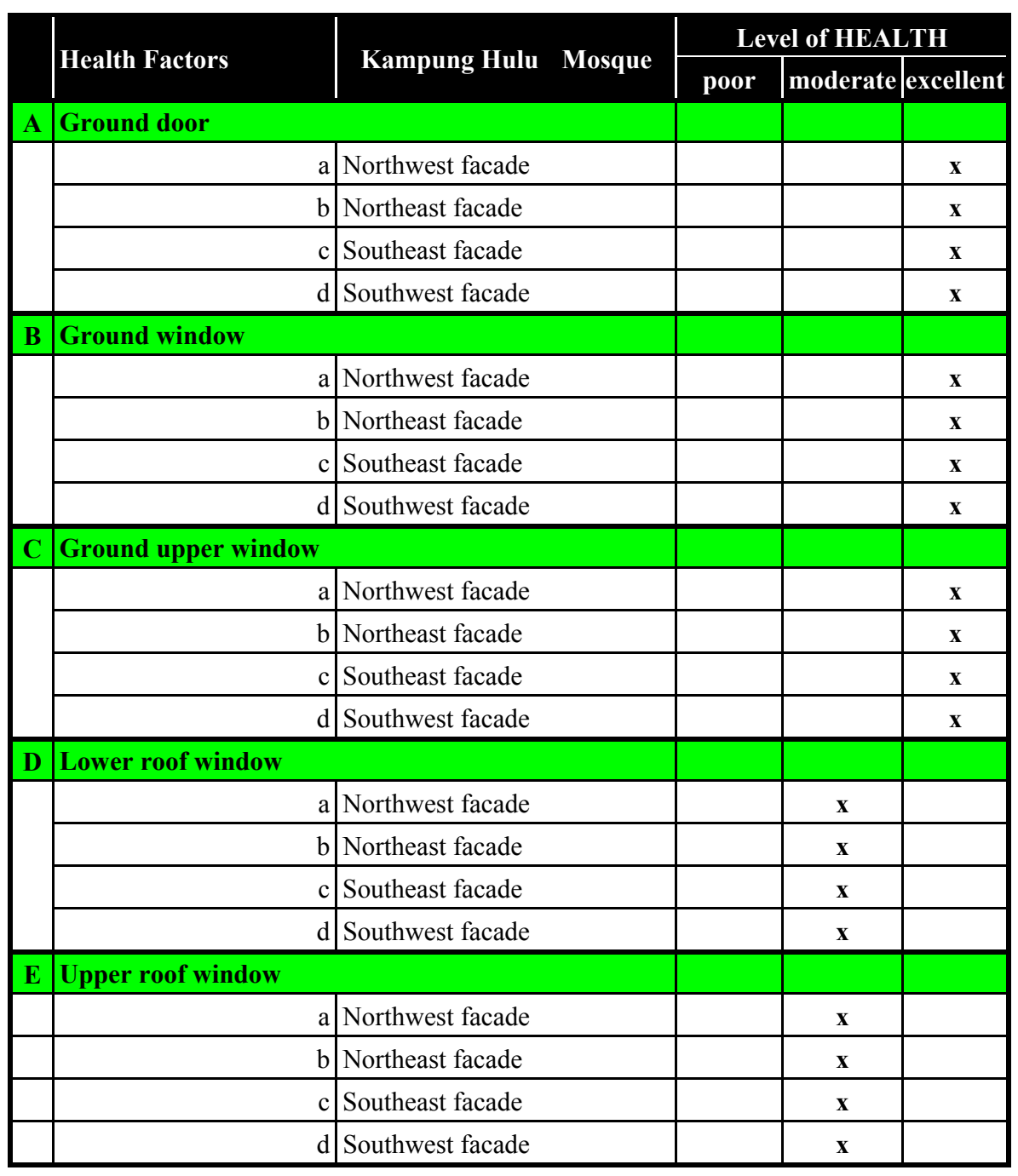

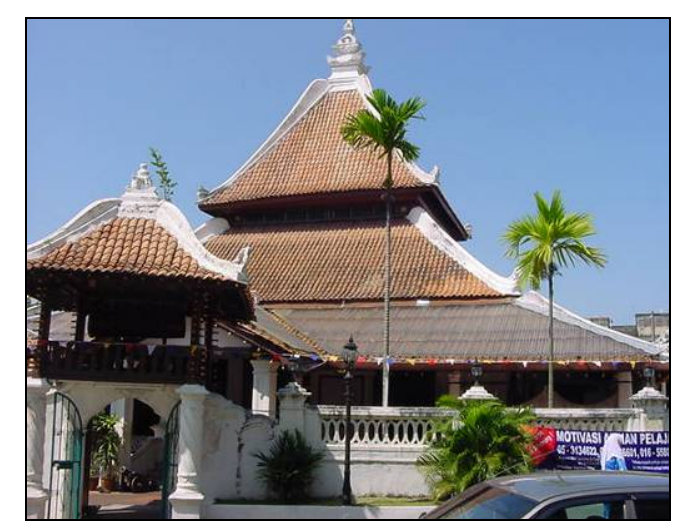

Figure 1. Front view of Kampung Hulu Mosque 


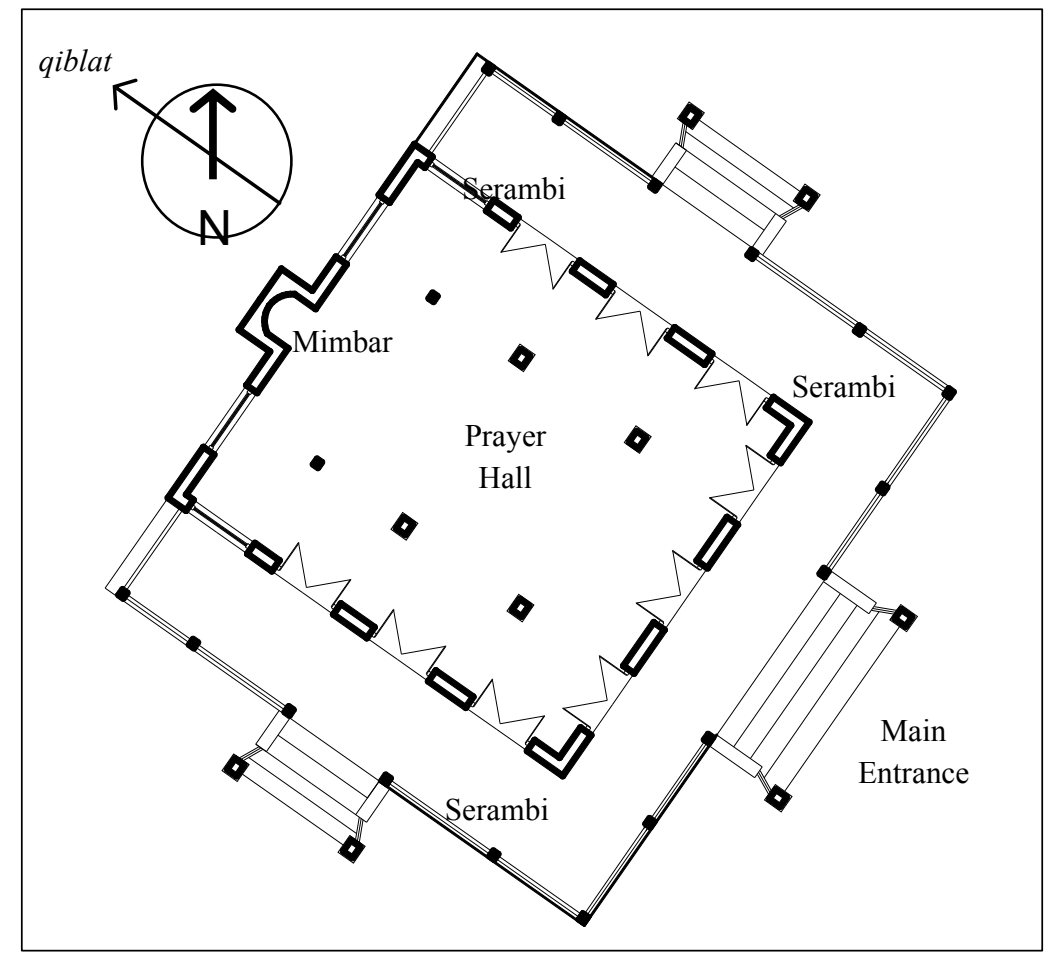

Figure 2. Plan Kampung Hulu Mosque

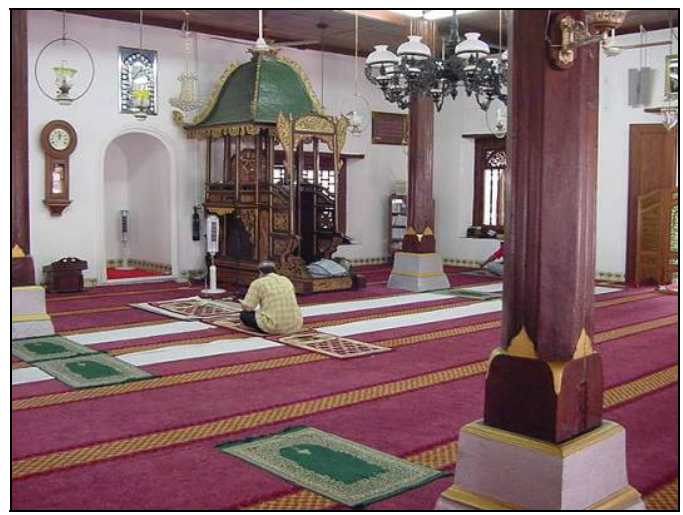

Figure 3. Prayer hall, mihrab and mimbar 

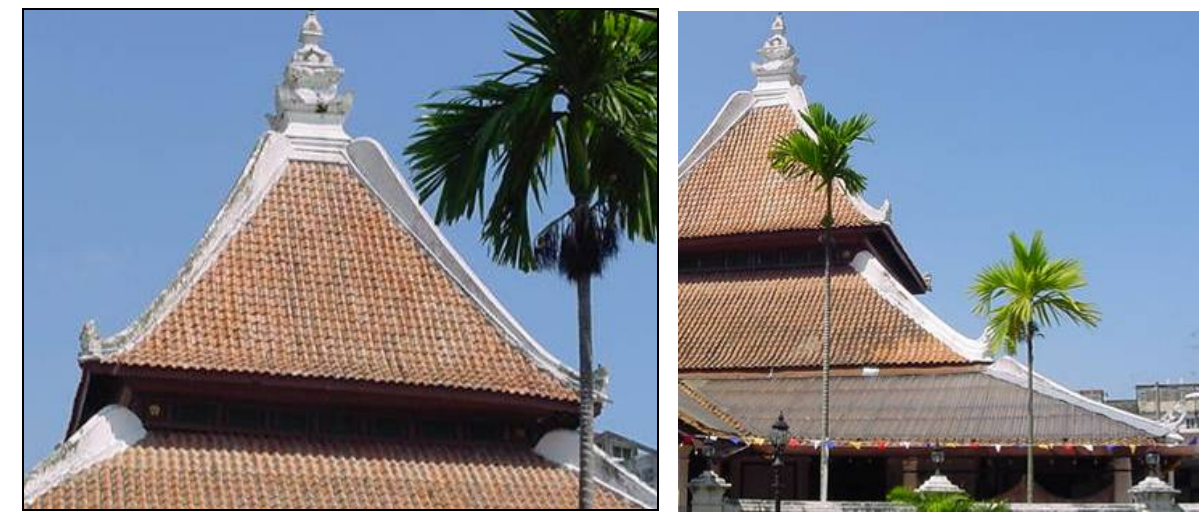

Figure 4. Pyramid roof shade (left) and attached roof system (right)

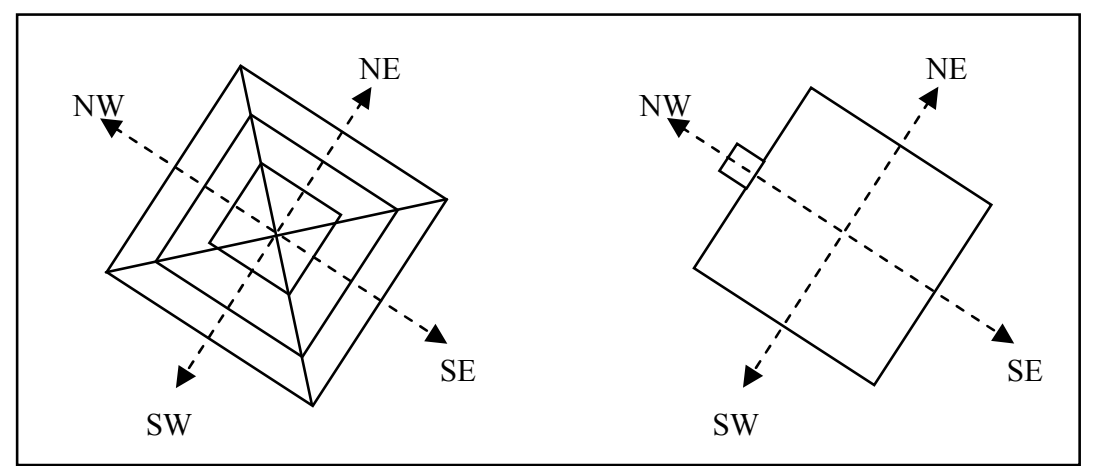

Figure 5. Building Orientation

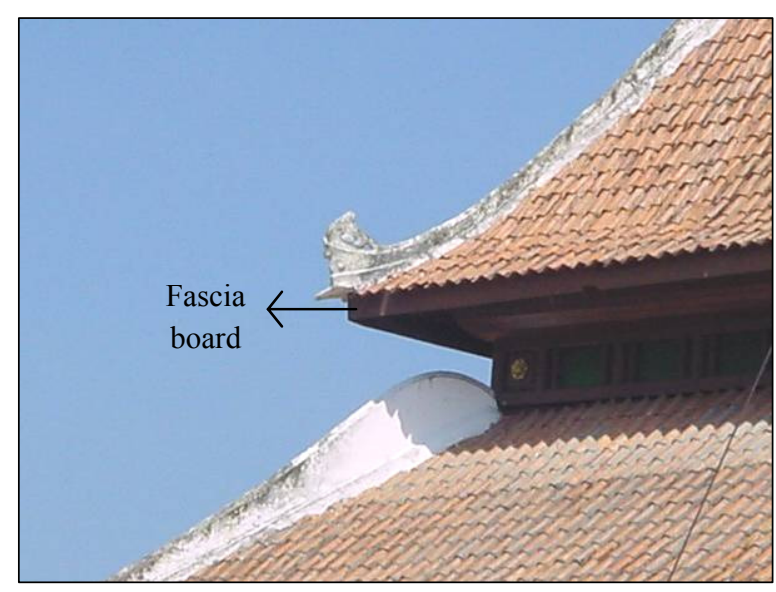

Figure 6. Fascia board 


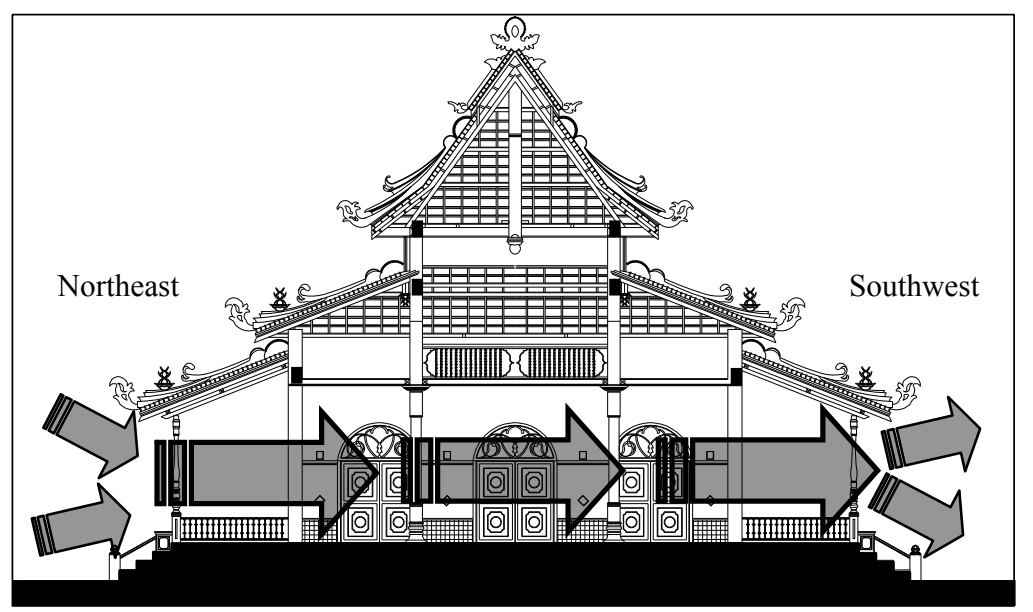

Figure 7. Cross air ventilation design analysis, viewing toward southeast facade
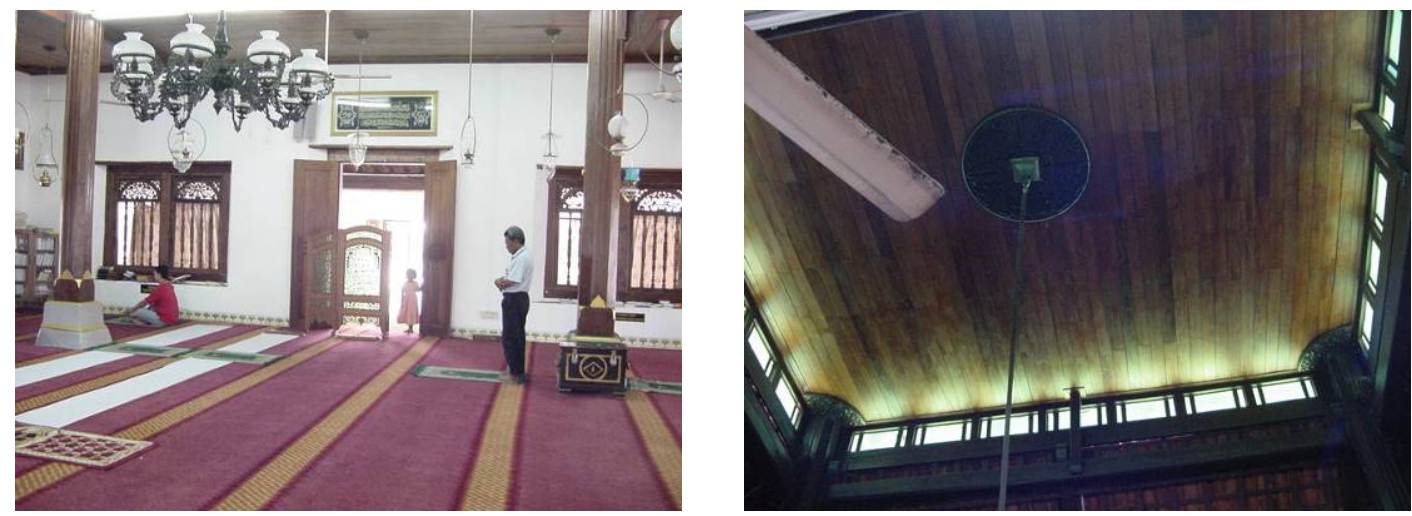

Figure 8. Wall openings (doors and windows) (left) and roof windows (right)

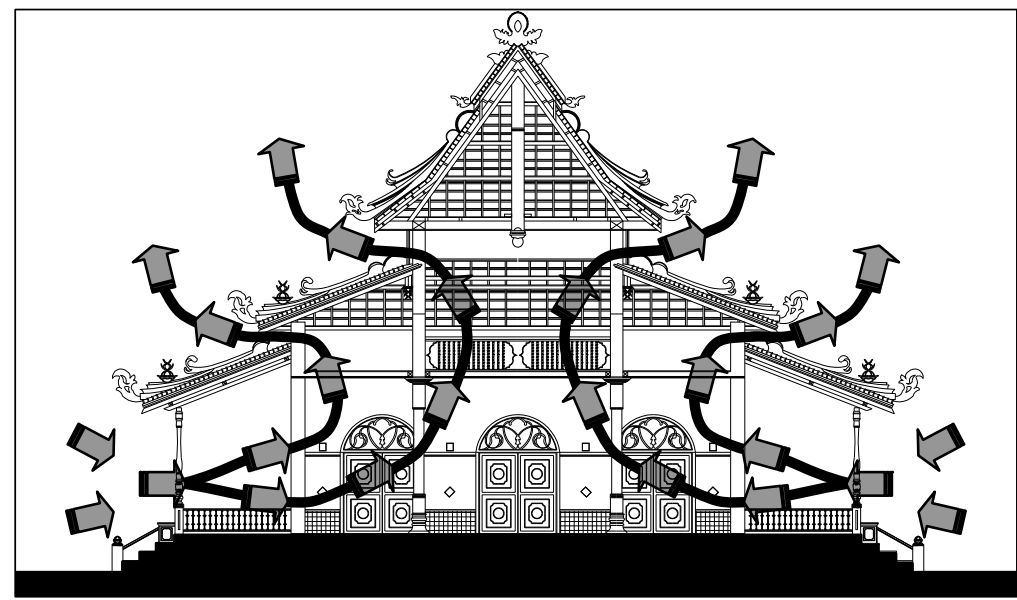

Figure 9. Stack effect design analysis 